\title{
Reflection on the Human Living Environment in Connection with Sustainable Development
}

\author{
Refleksja o środowisku życia człowieka w związku \\ ze zrównoważonym rozwojem
}

\author{
Wiesław Sztumski \\ University of Silesia in Katowice, 40-007 Katowice 11, Bankowa St., Poland \\ E-mails:ws34@op.pl,wieslaw2008@gmail.com, \\ ORCID: 0000-0002-6353-7206
}

\begin{abstract}
The author reflects on the possibility of implementing the idea of sustainable development in the environment of human life in various areas and between them. He begins by answering the question what is the human living environment, presents the typology of the areas that make up this environment and indicates the role of human in destroying it. Then, he analyzes selected pairs of areas of the human living environment that are opposite to each other (genuine - artificial, external - internal, natural - social, real - virtual, as well as local - global) because of the possibility of maintaining a balance within them and between them. The balance is a prerequisite for effective implementation of the idea of sustainable development. Finally, he made several conclusions resulting from his reflection.
\end{abstract}

Key words: human living environment, areas of the human living environment, sustainable development, balance, destabilization

\section{Streszczenie}

Autor zastanawia się nad możliwością realizacji idei zrównoważonego rozwoju w środowisku życia człowieka w różnych obszarach i między nimi. Zaczyna od odpowiedzi na pytanie, czym jest ludzkie środowisko życia, przedstawia typologię obszarów tworzących to środowisko i wskazuje na rolę człowieka w jego niszczeniu. Następnie analizuje wybrane pary obszarów ludzkiego środowiska życia, które są przeciwstawne sobie (naturalne - sztuczne, zewnętrzne - wewnętrzne, przyrodnicze - społeczne, realne - wirtualne, a także lokalne - globalne) ze względu na możliwość utrzymania równowagi w nich i między nimi. Równowaga jest warunkiem koniecznym dla skutecznego wdrażania idei rozwoju zrównoważonego. Na koniec wyciągnął kilka wniosków wynikających z tej refleksji.

Słowa kluczowe: środowisko życia człowieka, komponenty środowiska życia człowieka, rozwój zrównoważony, równowaga, destabilizacja

\section{The notion of human living environment}

The human living environment is a subdomain of the environment in a general sense, which, depending on which specialist uses the term, means 1) all nature, 2) the ecosystem, 3) external physical conditions affecting the growth, development, preservation and survival of humans, 4) all social and cultural conditions that shape the nature of individuals and communities.
The human living environment is something other than his surrounding, because it includes only those elements of surrounding, with which he interacts. Moreover, the life environment does not include what already someone has interacted with or what will interact with, but what currently interact with a human. However, at times such elements of the environment, at other times others of them interact with a human. Therefore, the life environment of a human changes constantly and requires updating. Humans and their living environment create a complementary 
and inseparable whole. However, it does not mean that they have to be in symbiosis.

The human living environment includes following components:

- All living organisms (humans and other creatures).

- Physical elements (phenomena, processes and events occurring in nature).

- Society and culture.

- Organizations, institutions and other elements of sociosphere as well as relationships between them and humans.

The human living environment consists of external (natural and social ecosystem) and internal ones. The external milieu includes objects, processes and natural and social phenomena. The internal one consists of components of the human mental structure (consciousness, intellect, personality, emotions, character and an internalized system of values, beliefs and spirituality) and his biological structure (anatomical and physiological). Primary component of the human living environment is the nature environment because nature has created the human species, nourishes it, keeps it alive and affects its development, evolution and fate. Instead, human-created environments - social, cultural, spiritual, etc. - are only secondary ones (Here, the words primary and secondary are used in both temporal and existential sense). Though the natural environment has created people, their existence and functioning also requires being in a social environment. That is why people must live in both environments; equally care for their quality, and especially for their balance.

\section{Is human a conscious or thoughtless enemy of his environment?}

In his evolution, the Homo sapiens destroy his external and internal environment proportionally to the progress of civilization, knowledge, technology, and population growth (The technology plays a particular role, because it allows people to interfere in nature and control it). This is due to the fact, that people's life has been and is a constant struggle against nature - why vivere militare est - and the possibility of survival depends on the victories over nature. Since modern times, especially in the human age (anthropocene), the fight against nature has become particularly uncompromising under the influence of capitalist system and Western civilization. People fight against nature not only in order to exist or survive, but also to have absolute power over it. $\mathrm{Hu}-$ mans fight against everything what is not them, what they consider as alien, and what they see as threat. Therefore, attitudes of hostility and aggression are spreading. This results in an increasingly rapid degradation of the natural and social environment as well as in numerous and frequent wars. For centuries war has been a terrible reality for millions of people.
Researchers from around the world are investigating why this is happening: What causes wars? What can you do about it? How can one reduce conflicts? Is it possible to help the injured - civilians and soldiers - in dealing with traumatic experiences? Is war in the biological nature of man or is it a product of culture? And, most importantly, are there still some unused paths to peace? (Ferguson 2008, p. 32) The wars between people destroy humanity directly, and wars against nature indirectly.

In uncompromising struggle for natural and social existence, and for domination in their environment people have forgotten that, willy-nilly, they form together with their environment an organic whole and have to keep the balance and harmony into their ecosystem. Long ago, Roman Ingarden wrote: Human forgot that his existence and life depend on what is happening in Nature and thinks that he can itself overcome Nature. However, all the time, he is forced to live on the ground of Nature and within it. He cannot believe and he does not want to believe that in any respect he is not better than animals or radically different from the rest of Nature (Ingarden, 1987, p. 14) Fortunately, the idea of sustainable development refreshes our memory about unity of human and his environment. It postulates to act on an ever-wider scale to maintain mechanisms ensuring homeostasis in the natural and social environment.

Nevertheless, despite the growing ecological awareness in many countries, the feeling the unity of a human with the rest of the world and responsibility for good quality of the environment are disappearing. (Sztumski, 2018) Therefore, destructive actions against the natural and social environment prevail over constructive ones. The more effectively people interfere with nature - of necessity or in good purposes - the more they destroy it. The environment is full of various toxins and waste that pose a threat to health and life of humans, animals and plants, and weakens their immune system. For this reason, various somatic and mental illnesses, called 'civilization diseases', become more and more widespread. It is increasingly difficult to prevent, and even harder to treat them. One estimates that the amount of organic waste originating from human activity is about two thousand times greater than in result of life activities of other species. Every year, 2.112 billion tons of waste appears in the world, and only from January to mid-July 2018, they were 1.15 billion tons (The world's counts, 2020). Not all waste is recyclable. Moreover, utilization and recycling cannot keep up with their growth. Environmentalists raise the alarm, because no species of living creatures can survive in an environment formed of waste. Nevertheless, economists and businesspersons, for whom commerce and profit are most important, do not listen to them. The progress of civilization led to the fact that humanity was faced with global ecological crises and the threat of complete extermination, and that for 
the first time in history the fate of the Earth and the people living on it was placed in the hands of people themselves. People can really avoid these threats or at least minimized them, if they will reasonably act and shape their correct relation towards the environment.

\section{On the issue of genuine and artificial environ- ment}

One divides elements of the environment into genuine and artificial. Genuine are those that are not created by man or were not deprived of their naturalness (denatured) by people because of machining, processing, deformation, degeneration or degradation. The number of genuine elements decreases faster and faster, due to not always thought-out activities. Artificial ingredients - material and intellectual artifacts - fill and overfill our environment. Recently, in the artifacts environment, virtual and digital elements - the products of programmers and computers - have emerged. Now, it is difficult to find some oasis of naturalness somewhere on Earth, where people are still immersed in nature, this primitive one, yet not defiled by human economy (Pilasiewicz, 2018, p. 7) Unfortunately, there are less and less such places in the world, their area is still shrinking as a result of technological and economic progress and mass tourism on a global scale. There is concern that such oases will disappear in the next future.

The genuine environment minimizes proportionally to the progress of Western civilization and to the expansion of artificiality. People need to get used to and constantly adapt to artificiality in their environment. That is why they are less and less aware of this phenomenon; they will still feel them less, react to him and fight him. They begin to treat artificiality as something genuine and do not see any differences between artificiality and genuity. The demarcation line between the genuine and the artificial blurs more and more also for objective reasons. What was once treated as artificial today is treated as genuine, and vice versa. Therefore, the concepts of genuity and artificiality will soon lose their traditional meaning and we will not know if we are still in a genuine environment or already in an artificial. It may happen that the environment, called genuine today, will turn into an environment of artifacts in the future, and our environment will transform itself into an artifact of the environment (Sztumski, 2016). Thus, the division into genuine and artificial environment will become groundless for subjective and objective reasons; at most, it may function as conventional. So far, people carelessly and often mindlessly fill their environment with an increasing number of different artifacts, above all with the synthetic products. They do it even for ecological and humanitarian reasons, but probably more from economic ones. For example, for the good and protection of animals one replaces genuine skins and furs by artificial ones. On the one hand, one protects some species of aquatic and terrestrial fauna; on the other hand, one litter the rivers, lakes and the sea with plastic waste or with artificial fertilizers are used in excess, what causes the death of many animals. One can cited many other commonly known examples of such contradictory activity of people. The disproportions between the genuine and artificial environment increase constantly in favor of the artificial environment what causes the increase of imbalance between them. This makes it improbable to restore the balance between genuity and, and thus to realize the prerequisite for building a sustainable environment in the future.

\section{Natural and social environment}

Traditionally, one divides environment into natural and social. The natural environment (geobosphere or cosmobiosphere) includes all elements of nature in the areas of physical, chemical, geological and biological objects, phenomena and processes. They are in the cosmosphere, physiosphere, lithosphere, atmosphere, hydrosphere and biosphere. The social environment (the mostly understood as sociosphere) consists of humans with their attitudes, behavior, activity and experiences, and of all their products, which affects their life. In particular, elements of the social environment are individuals and communities, organizations and institutions as well as interpersonal relations. In the social environment, there are also domains of culture and knowledge, of artifacts, of values (axiosphere), of technological activity (technosphere), of activities of human intellect (noosphere), of spirituality (pneumosphere), of social space and time, of virtuality (cybersphere), and of relationships and mutual interactions between people. The social environment also includes subdomains of education, work, economy, politics, urbanism, etc. Currently, this division into the natural and social environment is not as sharp as it used to be; it is rather traditional and symbolic. In the anthropocene period, it progresses continually and ever faster the positive feedback between the natural and social environment. That is because of the progress of civilization. Proportionally to the increase in human interference in nature, the natural environment becomes humanized and as if socialized. So, it gradually transforms into social environment. However, the positive feedback between the natural and social environments - contrary to expectation - does not contribute to maintaining a balance between them. That is because, in general, the natural environment evolves and changes slower (except for some catastrophic events) than the social one. The growing independence of people from nature is accompanied by an increasing weakening of homeostasis in the nature-society system, deepening asymmetry and an increase of internal contradictions. Thus, one of the necessary conditions to shape a sustainable environment in the future - the ensuring a balance between 
the natural and social environment - cannot be realized.

\section{Internal and external environment}

People's life is influenced by what surrounds them and what is inside them. In the first case, it is about the external environment (ectosystem) and in the second - about the internal one (endosystem). (Sztumski, 2004). Each of these determines human life in their own way, and depending on specific situations. There are times in our life, especially extreme ones, when the impact of the internal environment is much greater than the impact of the external environment. Then we can counteract external conditions truly effectively. There are well known the cases, as for example miraculous healings, when the strong will, unwavering character, huge emotions and mental resistance decided about the fate, life or the success of a person. Both environments condition each other because of mutual interactions. However, the ectosystem is more resistant to endosystem influences than vice versa. The impact of consciousness on what surrounds us is insignificant, especially in the case of individual consciousness; it is greater in the case of collective and social consciousness. The internal environment changes much more under the influence of the external one. That is well known by the behaviorists. The increased interest of people in various trainings and exercises aimed at improving their internal environment, for example survival schools, gyms, recreational activity, fitness, yoga, psychological workshops, etc., indicates the importance of the internal environment. The demand for strengthening body and soul results from defense reaction against the stressful social environment and degraded natural environment, thus, from the desire to survive in increasingly difficult conditions. Nevertheless, the changes in the internal environment do not keep up with the changes in the external environment, because the development of one and the other occurs unevenly. This causes a growing imbalance between the external and internal environment, which is an obstacle to sustainable development. The precondition for implementing sustainable development is an internally balanced man who cares for balance in his internal environment, as well as for a balance between the internal and external environment. (Sztumski, 2017).

\section{Real and virtual environment}

It is difficult to define a real environment, which according to one philosophical concept belongs to the sensory world, and according to others - to the ideal world. In principle, everyone senses what real is intuitively and without philosophical knowledge, but he cannot define it in a way that would raise no doubt. Usually, the word real is identified with the words: existing (or truly existing), true, factual, ob- jective, current, experienced, physical, observable, etc. Various definitions of the real world refer to these words, but especially to the word factual, as for example The real world is the place in which one actually must live and the circumstances with which one actually must deal (Your dictionary, 2020). Objections regarding different definitions of the real environment will become clear when confronted with the definition of the virtual environment. Besides, it seems that it is easier to define a virtual environment than a real one.

The virtual environment is a special type of artificial environment, created thanks to IT technologies. This environment consists of different virtual creatures, objects, and institutions, created by computer users. It is a multimedia and interactive simulation of the real (sensory or imaginary) environment: avatars, icons, emoticons, e-stores, e-money, e-books, emagazines, internet radio and TV, social and community portals (face books, Linkedin's, twitters), websites, communicators, e-education, e-society, eadministration, e-technology, e-commers etc. One can experience it (recognize and research), actively participate in its functioning and communicate within it with other computer users. Based on the definition of Mark W. Bell and several partial definitions, I suggest the following understanding of the virtual environment. Virtual environment is a synchronous, persistent network of people represented by avatars, which functions thanks to a system of computers connected to each other. Using computers, one can equipped them with features other than those of their correlates in the real environment. In particular, the laws of physics, causation, irreversibility of time, and even a logical sequence of events need not apply to it. The virtual environment is durable Internet-based, computer-rendered space (its computer images are created realistically), filled with hundreds, thousands and millions of people at once. The virtual environment is a space created for the use of an ever-expanding online community that perceives them and feels them almost the same as the real environment. Virtual environment realizes the same functions as the real one. Moreover, according to the epistemological and ontological criteria of existence, it even exists really, objectively, currently, actually and physically. Hence, people often confuse it with the real environment. People experience the being in it just as much as in a real one. It differs from the real environment that it is often invented and fictitious, and therefore false according to the classical (Aristotelian) definition and criterion of truth, but not according to other definitions and criteria of truth. As in the case of natural and artificial environments, the virtual environment develops much faster than the real one. Virtual environment is an interactive reproduction of the real environment due by computers using various types of sensory information, mainly acoustic and visual ones. This mapping can be more or less adequate copy of the 
real environment, or it can be fully fantastic, that is, such, which absolutely cannot take place in the ordinary real environment (A special case of a virtual environment is the digital environment. It is a mathematical representation of the real environment by means of appropriate combinations of digits numbers and functions. I treat them as a special form of virtual environment because not all can be mathematized).

The huge expansion of computers and robots contributes to the growing advantage of virtual over real elements in our environment. Soon, the virtual environment will increasingly affect people and decide about their life. People will have to live above all in a virtual environment, spend more and more time in it and experience it more and more. A virtual environment will much more form the functioning, the way of thinking, physical and intellectual development, attitudes, behavior and activity of humans than a real one. Therefore, the imbalance between the real and virtual environment will progress in the future the virtual environment will increasingly prevail over the real one. That will not be at all helpful in implementing the idea of sustainable development of human living environment.

\section{Local and global environment}

The term local environment means the space closest to man due to physical, social and psychological distance. It is an area, where he stays and interacts with other people, where he meets everything what is natural, social, cultural, physical and spiritual. The size of the local environment is relative as it depends on the subjective or intersubjective feeling of distance, intimacy and privacy. Often, one reduces it to various dimensions, such as educational (educational environment), occupational (work environment), ethnic, national or state (small homeland), psychological (human identity), denominational (religious environment), economic (business environment) etc. A characteristic of the local environment is the strong interaction between people and the components of the environment and the resulting strong relationships (bonds) between people and between people and the components of the environment. This relationship is the stronger, the longer a person stays in such an environment and the more it is friendly to it and favors it. This contributes to the fact that the local environment is stable, balanced and resistant to external interference. However, despite this, there are always contradictions and conflicts in the local environment. They are unavoidable and appear in consequence of various differentiations accompanying changes and development. They contribute to destabilization and imbalance, which leads to the degradation of this environment and even to its disintegration.

The term global environment refers to our entire planet. It consists on local environments - from the smallest to the largest. It is not homogeneous, but differentiated depending on the geographical location, climate zone, continents, lands, civilization level, economic and technological development and many other factors. In a global environment, networks of different connections and relationships between the nearest and most distant regions, and the events that occur in them intertwine. Therefore, the state of the global environment depends on the states of local environments and vice versa. For example, if a volcano erupts somewhere, it can affect the entire planet (butterfly effect). If the average temperature of the planet increases significantly, then the effects of this will be seen in local environments (ecosystems) around the world. However, people often ignore the impact of harmful local activities on the global environment. They do not realize that what is happening in a distant place can ultimately threaten their local environment. Their ecological thinking does not go beyond the horizon of their local environment. So far, the global environment is more stable than the local ones, because it has more durable homeostasis mechanisms, due to which it changes very slowly. (For various reasons, the fast and turbulent quantitative and qualitative changes take place in local environments), The homeostasis mechanisms operating in a global environment can restore balance in local environments. One not knows, however, how long it will be so. Perhaps, when unbalanced processes that disturb the balance of the global environment exceed a certain critical moment, then it will be more difficult to control them and homeostatic mechanisms of the global environment will appear powerless.

\section{Conclusions}

- It seems impossible to define precisely the human living environment on the base of some synthetic definition.

- Human living environment consists of many types of environments. Each of them consists of various domains and subdomains.

- In the extreme case, due to the globalization processes the entire globe becomes the human living environment.

- The demarcation lines between these environments become more and more blurred. Consequently, many common areas appear.

- Human species is the biggest enemy of environment. It destroys not only its own environment, but also environments of other living organisms.

- People guided by the irrational pursuit to dominate over nature and other living beings act often thoughtless.

- Imbalance processes progress and intensify in every component of people's living environment. 
- Natural homeostasis mechanisms will soon not be able to prevent it.

- It is unlikely that the idea of sustainable development could be fully realized in the human living environment.

\section{References}

1. FERGUSON B. R., 2008, Ten points on war, in: Social Analysis 52(2), p. 32.

2. INGARDEN R., 1987, Książeczka o człowieku (A book about human), Wydawnictwo Literackie, Cracow.

3. PILASIEWICZ Z., 2018, Podróż (Journey), Białystok.

4. SPEKTRUM, Krieg und frienden, https://www.spektrum.de/thema/krieg-und-frieden/1435408 (31.7.2018).

5. SZTUMSKI W., 2004, My, zagubieni $w$ świecie przyczynek do filozofii środowiska życia jako podstawy enwironmentologii (We, lost in the world $-a$ contribution to the philosophy of the living environment as the basis of environmentology), Wydawnictwo Uniwersytetu Śląskiego, Katowice.

6. SZTUMSKI W., 2006, Człowiek w środowisku artefaktów (A man in an environment of artifacts), in: Problemy ekologii, 6.

7. SZTUMSKI W., 2016, Środowisko artefaktów i artefakt środowiska (The environment of artifacts and the artifact of environment), in: $\Sigma O \Phi I A, 16$.

8. SZTUMSKI W., 2017, Sustainable DevelopmentSustainable Man (External and Internal Conditions for Sustainability), in: Technology, Society and Sustainability, ed. Zacher L.W., Springer International Publishing AG.

9. SZTUMSKI W., 2018, Durable Development and Responsible Development, in: Problemy Ekorozwoju/ Problems of Sustainable Development, 13(1), p. 113-120.

10. The world scounts, http://www.theworldscounts. com/counter (15.07.2018).

11. Your dictionary, Real world, http://www.yourdictionary.com/real-world (15.07.2018). 